\title{
Screening for drought resistance during germination of modern and old Iberian wheat cultivars
}

\author{
Ivo Pavia ${ }^{1}$, Luís Rocha ${ }^{1}$, José Moutinho-Pereira ${ }^{1}$, José Lima-Brito ${ }^{1,2,3}$, Carlos Correia ${ }^{1 \star}$ \\ ${ }^{1}$ CITAB - Centre for the Research and Technology of Agro-Environmental and Biological Sciences, University of \\ Trás-os-Montes and Alto Douro, 5000-801 Vila Real, Portugal \\ ${ }^{2}$ Department of Genetics and Biotechnology, University of Trás-os-Montes and Alto Douro, 5000-801 Vila Real, Portugal \\ ${ }^{3}$ BioISI-UTAD - Biosystems \& Integrative Sciences Institute-University of Tras-os-Montes and Alto Douro, Portugal
}

\begin{abstract}
Climate change is expected to reduce water availability in several wheat (Triticum aestivum L.) growing areas. Drought, during and immediately after sowing can compromise germination, seedling development, and ultimately crop yield. Our study's objective was to investigate early drought stress resistance and evaluate genetic diversity of four bread wheat cultivars - three modern elite germplasm lines ('Antequera', 'Jordão' and 'Roxo') and an ancient Portuguese cultivar ('Mestiço') - at five water potentials, ranging from 0 to $-1.5 \mathrm{MPa}$. Germination was annotated daily during eight days. Dry and fresh weights as well as root and shoot growth were measured. Genetic variability among cultivars was evaluated using start codon targeted (SCoT) markers. Overall, when water potential was lowered, germination rate and seedling growth were delayed. Final germination percentages were only affected by the higher stress intensity. This study reinforces the importance of research into ancient wheat cultivars, such as 'Mestiço'. This cultivar showed the highest genetic difference when compared with the remaining cultivars. 'Mestiço' presented the highest coleoptile size, high vigor index values, and the lowest variation in water content due to stress conditions. Therefore, it may be able to germinate in extremly dry soil and be the least affected by drought stress. Still, due to the comparatively reduced yield of older wheat cultivars, stress tolerance should be researched within elite cultivars. Among these, Jordão revealed particularly good germination and early biomass development characteristics across water potentials, presenting a likely choice for future studies under drought stress conditions.
\end{abstract}

Keywords: ancient wheat cultivar, drought, genetic diversity, germination, Triticum aestivum

\section{Introduction}

Wheat (Triticum spp.) is one of the most important staple crops worldwide (Schillinger et al. 2008). Dryland wheat farming in Mediterranean climates is highly dependent on winter precipitation and overwinter water storage in the soil. Climate change may cause many dryland production areas to become even drier, compromising the germination, emergence and overall yield of rainfed bread wheat (Triticum aestivum L.) (Eitzinger et al. 2003, Singh et al. 2013).

Seed germination is critical in the early stage of growth in most plants and may determine the success of crop production (Finch-Savage and Bassel 2016). Drought is an important environmental factor that negatively affects seed germination and seedling growth in dryland soil (Singh et al. 2013, Khayatnezhad and Gholamin 2011). The effects of drought stress can be mimicked resorting to polyethylene glycol (PEG). PEG is a non-ionic water polymer that is not expected to penetrate the plant tissue rapidly, thus compromising water uptake (Almansouri et al. 2001).
Genetic diversity analysis and fingerprinting in cereals have been successfully carried out by start codon targeted (SCoT) markers (Cabo et al. 2014, Pour-Aboughardareh et al. 2017). These are highly polymorphic functional markers based on the short-conserved region in plant genes surrounding the ATG translation start codon (Collard and Mackill 2009). Ancient wheat cultivars present an important group of genetic resources and may present abiotic stress tolerance characteristics (Martins-Lopes et al. 2009, Carvalho et al. 2010). Nonetheless, possible stress tolerance characteristics within elite crop germplasm should not be disregarded (Gilliham et al. 2017).

Our objective was to quantify early drought stress resistance and evaluate genetic diversity of four winter wheat cultivars - three modern elite germplasm lines developed in the Iberian Peninsula ('Antequera,' 'Jordão' and 'Roxo') and an ancient Portuguese bread wheat cultivar ('Mestiço').

\footnotetext{
*Corresponding author e-mail: ccorreia@utad.pt
} 


\section{Materials and methods}

Seeds of durum wheat (Triticum durum Desf.) 'Core' and bread wheat (Triticum aestivum L.) 'Antequera', 'Jordão', 'Roxo' and 'Mestiço' were used in this study. Seeds of durum wheat and modern (elite) bread wheat 'Antequera', 'Jordão' and 'Roxo' were stored at the Plant Breeding Station, Elvas (Portugal). Seeds of 'Mestiço' were obtained from the Plant Germplasm Bank, at the Department of Genetics and Biotechnology, University of Tras-os-Montes and Alto Douro, Vila Real (Portugal).

Seeds of T. aestivum were disinfected using a solution of sodium hypochlorite $1 \%$ for $3 \mathrm{~min}$ and then washed with distilled water. Twenty seeds per cultivar/treatment (in 3 repetitions) were germinated in $90 \mathrm{~mm}$ Petri dishes with filter paper moistened with polyethylene glycol solutions (PEG$6000)$ of $0,-0.33,-0.75,-1$ and $-1.5 \mathrm{MPa}$ water potential in the dark at $25^{\circ} \mathrm{C}$. Germination was annotated daily during eight days. PEG solutions were changed at the fourth day. Germinability $(\mathrm{G})$, mean time of germination (MT), mean germination rate (MR) and synchrony of germination $(\mathrm{Z})$ were calculated according to Ranal et al. (2009). Five days after seed germination, longest root and coleoptile growth as well as dry and fresh weight were measured in fifteen seedlings per cultivar $\times$ water potential combination. Water content was calculated based on these values. Vigor index (VI) was calculated based on coleoptile length and germinability according to Kumari et al. (2014). Logit transformation was performed in data expressed in proportion/percentage $(G$ and water content) prior to statistical analysis; original values are shown. ANOVA and Tukey post-hoc analysis were performed in IBM SPSS Statistics V23.

DNA was extracted from bulks of seven seedlings from each cultivar using DNeasy Plant Mini-kit (Qiagen) according to the manufacturer's instructions. DNA integrity was checked by electrophoresis on $1.5 \%$ agarose gels, quantified on Nanodrop ND-1000, and diluted to $30 \mathrm{ng} \mu \mathrm{L}^{-1}$. DNA amplification was performed with 8 SCoT primers (Fig. 1a) developed by Collard and Mackill (2009). Reaction mixture was made as reported by Cabo et al. (2014) and PCR conditions were as follows: initial denaturation of $3 \mathrm{~min}$ at $94{ }^{\circ} \mathrm{C}$ followed by 35 cycles of $1 \mathrm{~min}$ at $94^{\circ} \mathrm{C}, 1 \mathrm{~min}$ at $50^{\circ} \mathrm{C}$ and 2 min at $72^{\circ} \mathrm{C}$; final extension was of $5 \mathrm{~min}$ at $72^{\circ} \mathrm{C}$. Bands were scored as described by Cabo et al. (2014). Genetic similarity among cultivars was accessed by an unweighted pair group method using arithmetic averages (UPGMA) dendrogram of genetic similarity constructed with the software “NTSYS-pc, Numerical Taxonomy System” (Rohlf, 1998).

\section{Results and discussion}

\section{Dynamics of seed germination}

Wuest and Lutcher (2012) reported critical water potentials for $75 \%$ germination of several dryland wheat cultivars to be between -1.1 and $-1.6 \mathrm{MPa}$. By contrast, Singh et al. (2013) achieved $75 \%$ germination only at $-0.75 \mathrm{MPa}$ and no germination at $-1.5 \mathrm{MPa}$ in five commonly rainfed winter wheat cultivars. Here, although all cultivars' germinability (G) decreased at $-1.5 \mathrm{MPa}$, we did not observe com- plete germination inhibition. $\mathrm{G}$ of modern cultivars reached near $100 \%$ from 0 till $-1 \mathrm{MPa}$, while that of Mestiço was around $80 \%$ (Tab. 1). The low $\mathrm{G}$ value registered in Mestiço might not reflect a characteristic of this cultivar. Mestiço was not stored at the same location as the remaining cultivars, which might have significantly influenced germination performance (Wuest and Lutcher, 2012). Germinability was only affected when the higher stress level was applied (Tab. 1). At $-1.5 \mathrm{MPa}$, overall G dropped to $64.2 \%$. In Antequera and Jordão it dropped to 71.7 and $78.3 \%$, respectively, while in Mestiço it fell to 58.3\%. In Roxo it dropped steeply from 95\% at $-1 \mathrm{MPa}$ till $48.3 \%$ at $-1.5 \mathrm{MPa}$. Mean time of germination (MTG) steady increased with lower water potentials in all cultivars from near 1 till over 4 days (Tab. 1). Mean germination rate $(\mathrm{MR})$ was similar in all cultivars, with the exception of Mestiço, and decreased with the decrease of the water potential (Tab. 1). Synchrony of germination (Z) was overall higher in Antequera and Jordão (Tab. 1). The observed delay in germination with the decrease of water potential is consistent with the findings of other authors (Almansouri et al. 2001, Singh et al. 2013, Kumari et al. 2014).

\section{Early biomass production}

Drought highly affected fresh weight, while dry weight variation was only observed between cultivars (Fig. 2a). At $0 \mathrm{MPa}$ all cultivars showed similar water content, ranging from 84.67 till $89.45 \%$ (Fig. 2b). Mestiço showed the lowest variation in water percentage between 0 and $-1.5 \mathrm{MPa}$, with 89.45 and $45.81 \%$ respectively. The remaining cultivars dropped to values lower than $40 \%$ at $-1.5 \mathrm{MPa}$ (Fig. 2b). Khayatnezhad and Gholamin (2011) found that the effect of PEG on leaf area of 10-day-old plants was greater than the effect on fresh weight, leading us to believe that Mestiço, which showed the lowest water percentage variation across water potentials (Fig. 2b), will also be the least affected by the future growing reduction due to drought stress.

Drought stress decreased both root and shoot size (Fig. 3a). Field and laboratory experiments indicate that cultivars with long coleoptiles have superior emergence on deep seeding (Singh et al. 2013). The highest coleoptile growth was verified in Mestiço at $0 \mathrm{MPa}$, with an average of $8.22 \mathrm{~cm}$. Coleoptile length coupled with the ability of seeds to germinate at low water potentials are important factors controlling winter wheat seedling emergence (Singh et al. 2013). In contrast to the modern cultivars, Mestiço is a tall wheat variety (Maçãs, B. and Coutinho, J., unpublished data). Modern varieties assuredly have reduced height $(R h t)$ genes which have been associated with reduced coleoptile size (Ellis et al. 2004). This is a possible explanation for the reduced coleoptile size in modern cultivars when compared with Mestiço. Vigor index (VI) that considers both coleoptile length and germinability may present an important clue regarding cultivars ability to withstand drought stress. VI values ranged from 10.47 till 786.67 (Fig. 3b). VI was influenced by both cultivars and drought stress, as reported by others (Kumari et al. 2014). The highest values were observed, for all cultivars, at $0 \mathrm{MPa}$ and the lowest at $-1.5 \mathrm{MPa}$. The highest 
a)

\begin{tabular}{cccc} 
Molecular Marker & Sequence $\left(5^{\prime}-\mathbf{3}^{\prime}\right)$ & Number of bands & \% Polymorphism \\
\hline SCOT 11 & AAGCAATGGCTACCACCA & 8 & 37.50 \\
SCoT 21 & ACGACATGGCGACCACA & 7 & 85.71 \\
SCOT 22 & AACCATGGCTACCACCAC & 6 & 66.67 \\
SCOT 24 & CACCATGGCTACCACCAT & 10 & 40.00 \\
SCOT 25 & ACCATGGCTACCACCGGG & 8 & 50.00 \\
SCOT 33 & CCATGGCTACCACCGCAG & 15 & 73.33 \\
SCOT 34 & ACCATGGCTACCACCGCA & 3 & 66.67 \\
SCOT 36 & GCAACAATGGCTACCACC & 8 & 87.50
\end{tabular}
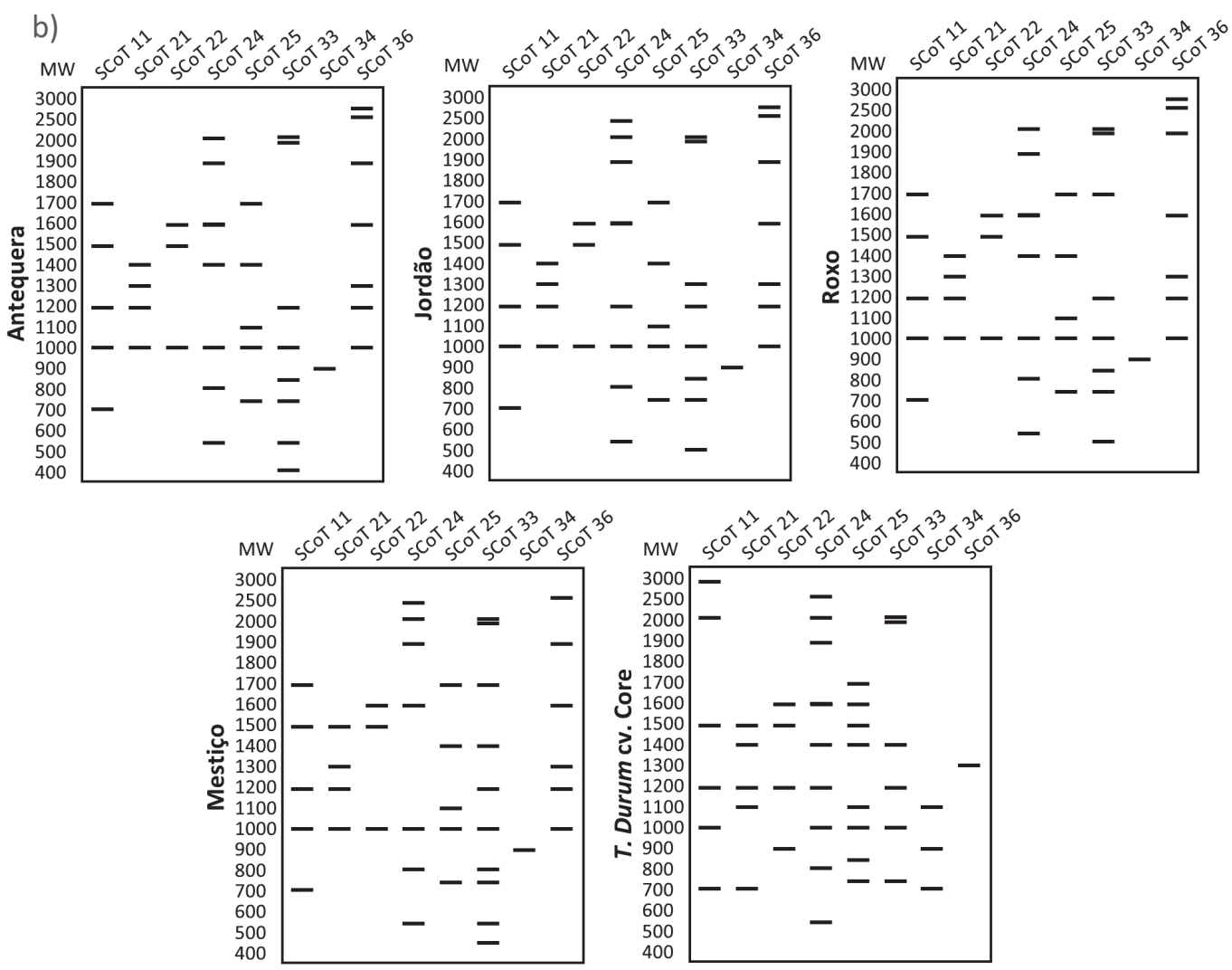

c)

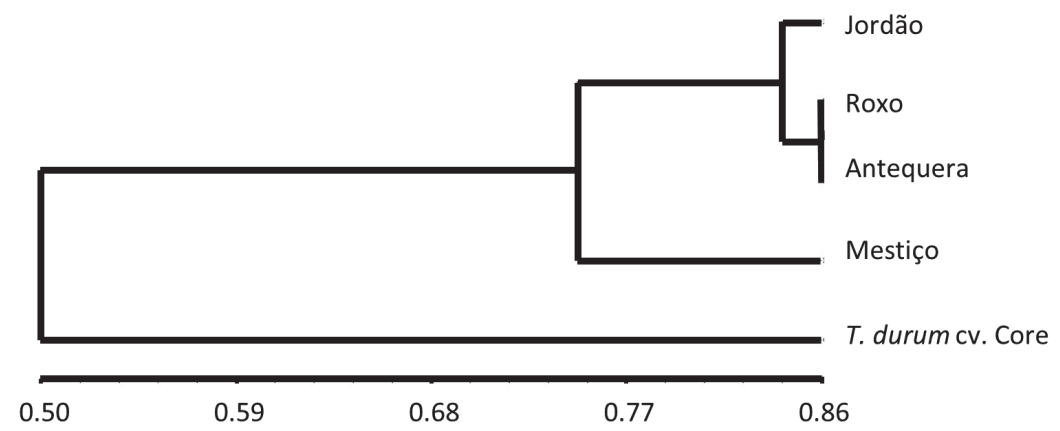

Fig. 1. Results of the genetic diversity analysis: (a) sequence, number of bands and polymorphism percentage of each start codon targeted (SCoT) marker, (b) genetic profile, based on DNA amplification with SCoT markers, of bread wheat (Triticum aestivum L.) 'Antequera', 'Jordão', 'Roxo' and 'Mestiço' and durum wheat (Triticum durum Desf.) 'Core; and (c) unweighted pair group method with arithmetic mean dendrogram of genetic similarity of the studied wheat cultivars; MW - molecular weight in base pairs.

averaged VI values across the different water potentials were observed in Mestiço and Jordão.

\section{Ancient wheat varieties as a source of genetic diversity}

Ancient bread wheat cultivars show a high genetic diversity (Carvalho et al. 2010) and interesting agronomic traits, such as aluminum resistance (Martins-Lopes et al. 2009).
Although the limitations of bulk analysis are recognized, low intra-cultivar variability is expected and it allows assessment of genetic variation among cultivars. SCoT markers showed an average of $64.6 \%$ of polymorphic bands (Fig. 1a). The genetic profile of each of the studied cultivars, based on the DNA amplification with SCoT markers, is presented in Figure 1b. Mestiço showed a higher genetic difference than the 
Tab. 1. Germination parameters in wheat cultivars on drought stress. Data are mean values $\pm S D, n=60$. G - germination percentage; $M T$ - mean time of germination; MR - mean germination rate; $\mathrm{Z}$ - synchrony of germination. Different letter $(\mathrm{a}, \mathrm{b}, \mathrm{c})$ correspond to statistical differences among results by the Tukey-test $(\mathrm{p}<0.05)$

\begin{tabular}{|c|c|c|c|c|}
\hline Cultivar (cv) & G (\%) & MT (day) & $\operatorname{MR}\left(\right.$ day $\left.^{-1}\right)$ & $\mathrm{Z}$ \\
\hline Antequera & $92.00 \pm 11.46 \mathrm{a}$ & $2.48 \pm 1.42 \mathrm{a}, \mathrm{b}$ & $0.531 \pm 0.271 \mathrm{a}$ & $0.656 \pm 0.216 \mathrm{a}$ \\
\hline Jordão & $94.00 \pm 9.30 \mathrm{a}$ & $2.28 \pm 1.15 \mathrm{a}$ & $0.549 \pm 0.260 \mathrm{a}$ & $0.683 \pm 0.223 \mathrm{a}$ \\
\hline Mestiço & $80.67 \pm 14.00 \mathrm{~b}$ & $2.69 \pm 0.98 b$ & $0.419 \pm 0.057 \mathrm{~b}$ & $0.490 \pm 0.159 \mathrm{a}, \mathrm{b}$ \\
\hline Roxo & $88.67 \pm 21.42 \mathrm{a}$ & $2.48 \pm 1.33 \mathrm{a}, \mathrm{b}$ & $0.519 \pm 0.265 \mathrm{a}$ & $0.597 \pm 0.247 \mathrm{~b}$ \\
\hline \multicolumn{5}{|c|}{ Water potential (W, in $\mathrm{MPa}$ ) } \\
\hline 0 & $95.83 \pm 6.34 \mathrm{a}$ & $1.16 \pm 0.23 \mathrm{a}$ & $0.884 \pm 0.140 \mathrm{a}$ & $0.804 \pm 0.209 \mathrm{a}$ \\
\hline-0.33 & $97.08 \pm 4.98 \mathrm{a}$ & $1.77 \pm 0.37 \mathrm{~b}$ & $0.586 \pm 0.112 \mathrm{~b}$ & $0.557 \pm 0.123 \mathrm{~b}$ \\
\hline-0.75 & $95.83 \pm 5.97 \mathrm{a}$ & $2.15 \pm 0.19 c$ & $0.469 \pm 0.041 \mathrm{c}$ & $0.748 \pm 0.171 \mathrm{a}$ \\
\hline-1 & $91.25 \pm 9.08 \mathrm{a}$ & $2.79 \pm 0.31 \mathrm{~d}$ & $0.363 \pm 0.044 \mathrm{~d}$ & $0.523 \pm 0.202 \mathrm{~b}, \mathrm{c}$ \\
\hline-1.5 & $64.17 \pm 14.72 \mathrm{~b}$ & $4.56 \pm 0.40 \mathrm{e}$ & $0.221 \pm 0.019 \mathrm{e}$ & $0.400 \pm 0.113 c$ \\
\hline \multicolumn{5}{|l|}{$\mathrm{cv} \times \mathrm{W}$} \\
\hline Antequera $\times 0$ & $96.67 \pm 5.77$ & $1.05 \pm 0.05$ & $0.954 \pm 0.045$ & $0.904 \pm 0.095$ \\
\hline Antequera $\times-0.33$ & $96.67 \pm 5.77$ & $1.59 \pm 0.25$ & $0.640 \pm 0.112$ & $0.523 \pm 0.075$ \\
\hline Antequera $\times-0.75$ & $96.67 \pm 2.89$ & $1.98 \pm 0.16$ & $0.506 \pm 0.040$ & $0.838 \pm 0.103$ \\
\hline Antequera $\times-1$ & $98.33 \pm 2.89$ & $2.86 \pm 0.31$ & $0.352 \pm 0.037$ & $0.554 \pm 0.151$ \\
\hline Antequera $\times-1.5$ & $71.67 \pm 5.77$ & $4.93 \pm 0.39$ & $0.204 \pm 0.016$ & $0.459 \pm 0.192$ \\
\hline Jordão $\times 0$ & $100.00 \pm 0.00$ & $1.03 \pm 0.03$ & $0.968 \pm 0.027$ & $0.933 \pm 0.058$ \\
\hline Jordão $\times-0.33$ & $100.00 \pm 0.00$ & $1.53 \pm 0.12$ & $0.655 \pm 0.052$ & $0.472 \pm 0.040$ \\
\hline Jordão $\times-0.75$ & $100.00 \pm 0.00$ & $2.10 \pm 0.13$ & $0.477 \pm 0.029$ & $0.835 \pm 0.205$ \\
\hline Jordão $\times-1$ & $91.67 \pm 7.64$ & $2.49 \pm 0.40$ & $0.408 \pm 0.062$ & $0.718 \pm 0.159$ \\
\hline Jordão $\times-1.5$ & $78.33 \pm 2.89$ & $4.23 \pm 0.33$ & $0.238 \pm 0.019$ & $0.459 \pm 0.043$ \\
\hline Mestiço $\times 0$ & $86.67 \pm 2.89$ & $1.52 \pm 0.13$ & $0.660 \pm 0.057$ & $0.477 \pm 0.051$ \\
\hline Mestiço $\times-0.33$ & $91.67 \pm 5.77$ & $2.26 \pm 0.34$ & $0.450 \pm 0.072$ & $0.632 \pm 0.141$ \\
\hline Mestiço $\times-0.75$ & $86.67 \pm 2.89$ & $2.38 \pm 0.11$ & $0.420 \pm 0.018$ & $0.541 \pm 0.125$ \\
\hline Mestiço $\times-1$ & $80.00 \pm 8.66$ & $3.00 \pm 0.06$ & $0.334 \pm 0.007$ & $0.437 \pm 0.266$ \\
\hline Mestiço $\times-1.5$ & $58.33 \pm 14.43$ & $4.31 \pm 0.02$ & $0.232 \pm 0.011$ & $0.363 \pm 0.071$ \\
\hline Roxo $\times 0$ & $100.00 \pm 0.00$ & $1.05 \pm 0.05$ & $0.954 \pm 0.045$ & $0.904 \pm 0.095$ \\
\hline Roxo $\times-0.33$ & $100.00 \pm 0.00$ & $1.70 \pm 0.28$ & $0.599 \pm 0.095$ & $0.602 \pm 0.177$ \\
\hline Roxo $\times-0.75$ & $100.00 \pm 0.00$ & $2.12 \pm 0.10$ & $0.473 \pm 0.024$ & $0.779 \pm 0.050$ \\
\hline Roxo $\times-1$ & $95.00 \pm 5.00$ & $2.80 \pm 0.22$ & $0.359 \pm 0.028$ & $0.384 \pm 0.084$ \\
\hline Roxo $\times-1.5$ & $48.33 \pm 10.41$ & $4.76 \pm 0.25$ & $0.211 \pm 0.011$ & $0.320 \pm 0.064$ \\
\hline \multicolumn{5}{|l|}{ p-values } \\
\hline $\mathrm{cv}$ & $\mathrm{p}<0.001$ & $\mathrm{p}<0.001$ & $\mathrm{p}<0.001$ & $\mathrm{p}=0.001$ \\
\hline $\mathrm{W}$ & $\mathrm{p}<0.001$ & $\mathrm{p}<0.001$ & $\mathrm{p}<0.001$ & $\mathrm{p}<0.001$ \\
\hline $\mathrm{cv} \times \mathrm{W}$ & $\mathrm{p}=0.044$ & $p=0.003$ & $\mathrm{p}<0.001$ & $\mathrm{p}=0.006$ \\
\hline
\end{tabular}

elite cultivars (Fig. 1c). This was expected as Mestiço is an ancient Portuguese wheat cultivar, not subjected to a modern breeding program. Such a distinction is also observed in the germination (Tab. 1) and growth responses (Figs. 2, 3). Among the studied cultivars, Mestiço may be the least affected by any future growing reduction due to drought stress (Khayatnezhad and Gholamin 2011). Introgression of alleles from ancient cultivars, such Mestiço, into modern ones can be useful when breeding for suboptimal environments, such as those prevalent in the Mediterranean Basin (Soriano et al. 2018). Furthermore, we propose future research into $R h t$ genes able to maintain reduced height in modern cultivars without affecting early growth, such as Rht8 (Ellis et al. 2004).

\section{Screening for drought resistance using PEG assays}

Development of stress-tolerant varieties is a core objective of many breeding programs. Still, success has been limited due to lack of adequate screening techniques (Kumari et al. 2014). Due to the vast number of ancient cultivars stored in germplasm banks, most are still to be agronomically characterized. Nonetheless, the use of ancient wheat cultivars in breeding programs may be useful when breeding for suboptimal environments such as those prevalent in the Mediterranean Basin (Soriano et al. 2018). We believe that PEG experiments, such as the one described here, are suitable for screening drought tolerance prior to field trials. This screening could significantly reduce the overall cost and manpower 
a)

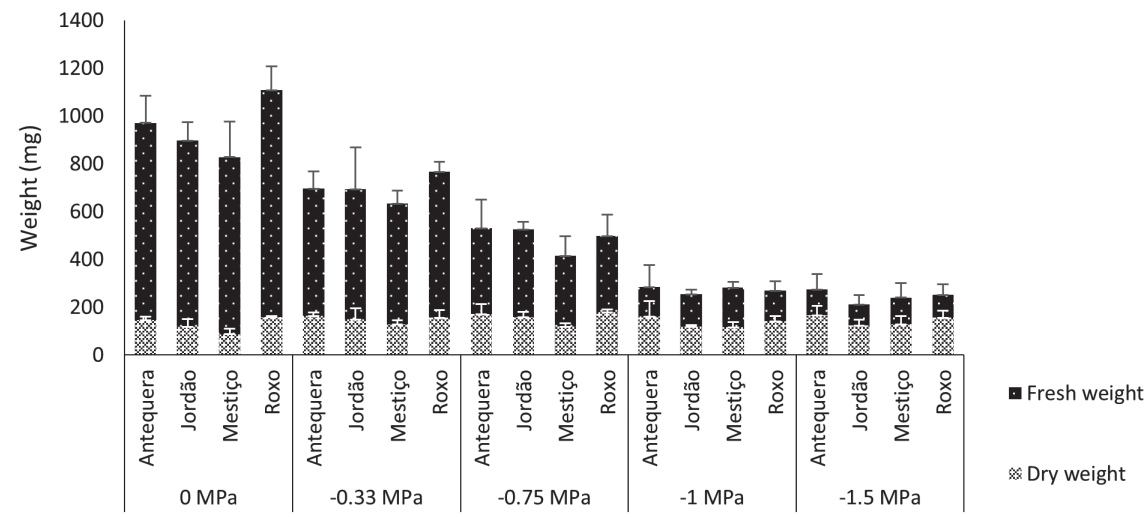

b)

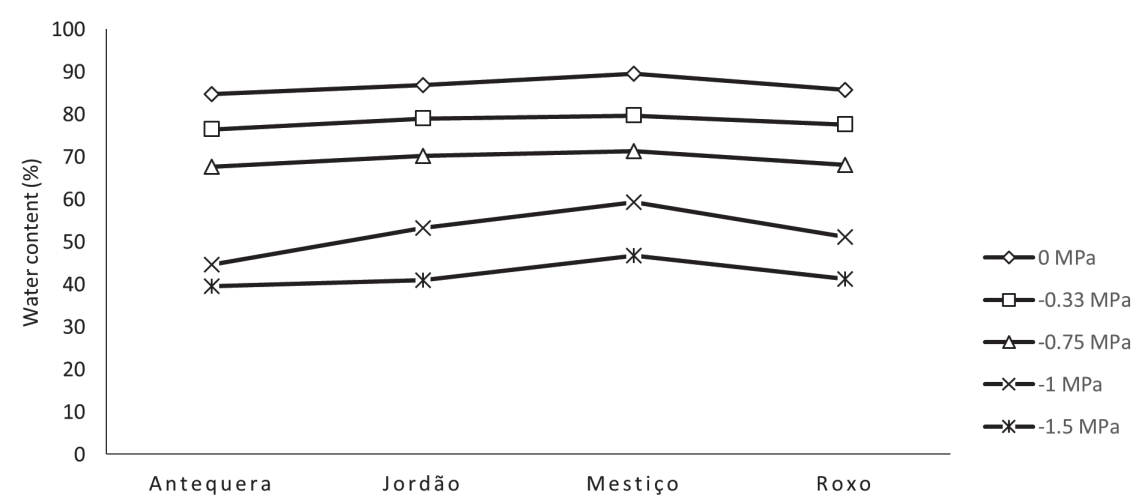

Fig. 2. Mean values of (a) fresh and dry weigh, and (b) water content of 5-day old seedlings of four Iberian cultivars at five water potentials, $\mathrm{n}=15$. Results of two-way ANOVA showed p-values for cultivar (cv), water potential (W) and the interaction of both factors (cv $\times \mathrm{W})$ for each parameter. p-values for fresh weight: $\mathrm{cv}=0.015, \mathrm{~W}<0.001, \mathrm{cv} \times \mathrm{W}=0.275$; p-values for dry weight; $\mathrm{cv}<0.001, \mathrm{~W}=0.047, \mathrm{cv} \times$ $\mathrm{W}=0.933$; p-values for water content: $\mathrm{cv}<0.001, \mathrm{~W}<0.001, \mathrm{cv} \times \mathrm{W}=0.049$.

a)

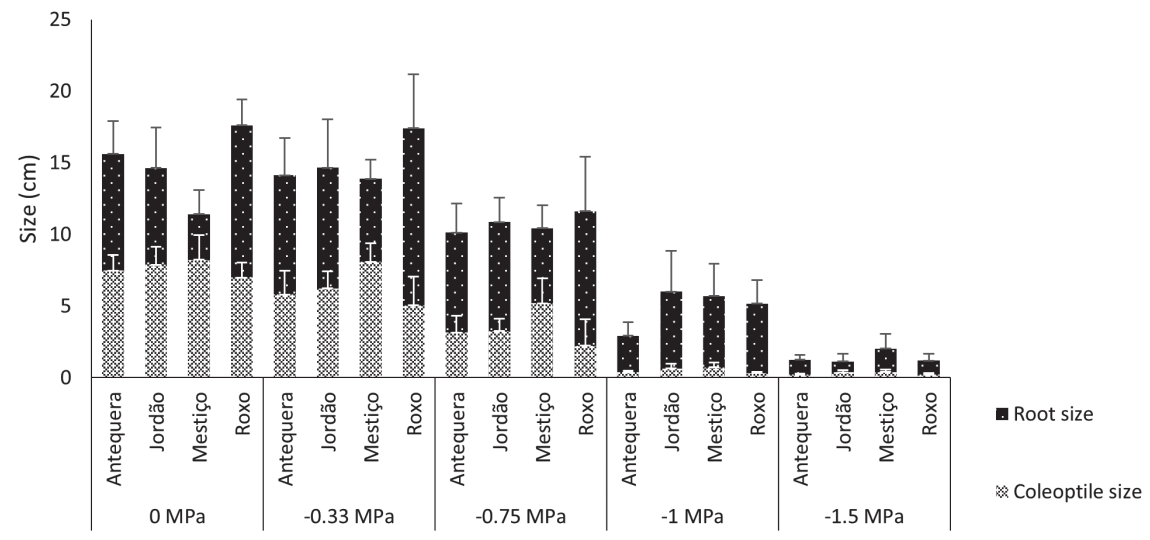

b)

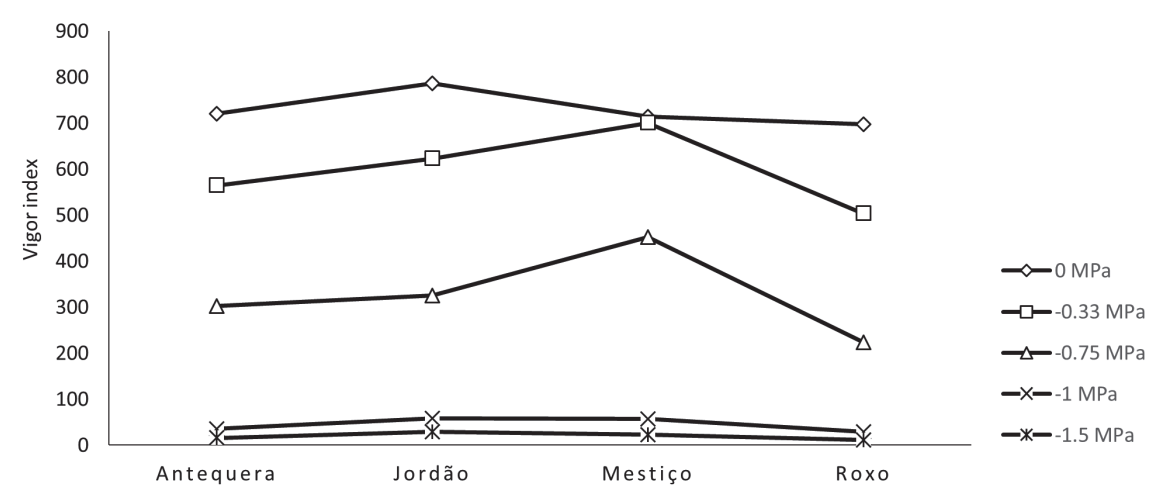

Fig. 3. Mean values of (a) root and coleoptile length, and (b) vigor index of 5-day old seedlings of four Iberian cultivars at five water potentials, $\mathrm{n}=15$. Results of two-way ANOVA showed $\mathrm{p}$-values for cultivar $(\mathrm{cv})$, water potential $(\mathrm{W})$ and the interaction of both factors $(\mathrm{cv} \times \mathrm{W})$ for each parameter. p-values for root length: $\mathrm{cv}<0.001, \mathrm{~W}<0.001, \mathrm{cv} \times \mathrm{W}<0.001$; p-values for coleoptile length: $\mathrm{cv}<0.001$, $\mathrm{W}<0.001, \mathrm{cv} \times \mathrm{W}<0.001$; $\mathrm{p}$-values for vigor index: $\mathrm{cv}<0.001, \mathrm{~W}<0.001, \mathrm{cv} \times \mathrm{W}=0.003$. 
required for field trials, as reported previously by others (Singh et al. 2013, Kumari et al. 2014, Gilliham et al. 2017).

\section{Conclusion}

This study reinforces the importance of research into ancient wheat cultivars, such Mestiço. This cultivar showed the highest coleoptile size, high VI values, as well as the lowest variation in water content due to stress conditions. All these features lead us to believe it may be able to germinate in extremely dry soil and may be the least affected by any future growing reduction due to drought stress. Still, to be relevant to breeders, research into improving stress tolerance should focus on elite cultivars. Paradoxically, breeding programmes have been traditionally focused on maximising yield, while disregarding abiotic stress tolerance. Among the modern cultivars, Jordão revealed particularly good germination charac-

\section{References}

Almansouri, M., Kinet, J.M., Lutts, S., 2001: Effect of salt and osmotic stresses on germination in durum wheat (Triticum $d u$ rum Desf.). Plant and Soil 231, 243-254.

Cabo, S., Ferreira, L., Carvalho, A., Martins-Lopes, P., Martín, A., Lima-Brito, J., 2014: Potential of Start Codon Targeted (SCoT) markers for DNA fingerprinting of newly synthesized tritordeums and their respective parents. Journal of Applied Genetics 55, 307-312.

Carvalho, A., Guedes-Pinto, H., Martins-Lopes, P., Lima-Brito, J., 2010: Genetic variability of Old Portuguese bread wheat cultivars assayed by IRAP and REMAP markers. Annals of Applied Biology 156, 337-345.

Coco, J., 2013: Adaptabilidade e estabilidade de produção de trigo mole - interação genótipo x ambiente. Master Thesis. Instituto Politécnico de Portalegre, Portalegre, Portugal.

Collard, B.Y., Mackill, D., 2009: Start Codon Targeted (SCoT) Polymorphism: A simple, novel DNA marker technique for generating gene-targeted markers in plants. Plant Molecular Biology Reporter 27, 86-93.

Eitzinger, J., Štastná, M., Žalud, Z., Dubrovský, M., 2003: A simulation study of the effect of soil water balance and water stress on winter wheat production under different climate change scenarios. Agricultural Water Management 61, 195-217.

Ellis, M.H., Rebetzke, G.J., Chandler, P., Bonnett, D., Spielmeyer, W., Richards, R.A., 2004: The effect of different height reducing genes on the early growth of wheat. Functional Plant Biology $31,583-589$.

Finch-Savage, W.E, Bassel, G.W., 2016: Seed vigour and crop establishment: extending performance beyond adaptation. Journal of Experimental Botany 67, 567-591.

Gilliham, M., Able, J.A., Roy, S.J., 2017: Translating knowledge about abiotic stress tolerance to breeding programmes. The Plant Journal 90, 898-917.

Khayatnezhad, M., Gholamin, R., 2011: Effects of water and salt stresses on germination and seedling growth in two durum teristics, such $\mathrm{G}$ and $\mathrm{Z}$ as well as VI values across water potentials. This elite cultivar, which has shown high and stable yield in various environments (Coco, 2013), presents a likely choice for future studies under drought stress conditions.

\section{Acknowledgements}

We thank Eng. Coutinho (INIAV-Elvas) for supplying seeds of durum wheat 'Core' and bread wheat 'Antequera', 'Jordão' and 'Roxo' stored at the Plant Breeding Station at Elvas (Portugal). The authors IP (PD/BD/113611/2015) and LR (PD/BD/113612/2015) acknowledge their doctoral grants funded by the FCT (Portuguese Foundation for Science and Technology) under the Doctoral Program "Agricultural Production Chains - from fork to farm" (PD/00122/2012). This work was also supported by National Funds by FCT, under the project UID/AGR/04033/2019.

wheat (Triticum durum Desf.) genotypes. Scientific Research Essays 6, 4597-4603.

Kumari, A., Sairam, R.K., Singh, S., Krishna, G.K., 2014: Early growth response: an indicator of subsequent growth and yield of wheat genotypes grown under simulated water stress condition. Indian Journal of Plant Physiology 19, 94-100.

Martins-Lopes, P., Maças, B., Guedes-Pinto, H., 2009: Portuguese bread wheat germplasm evaluation for aluminium tolerance. Cereal Research Communications 37, 179-188.

Pour-Aboughadareh, A., Ahmadi, J., Mehrabi, A.A., Etminan, A., Moghaddam, M., 2017: Assessment of genetic diversity among Iranian Triticum germplasm using agro-morphological traits and start codon targeted (SCoT) markers. Cereal Research Communications 45, 574-586.

Ranal, M.A., Santana, D.G.D., Ferreira, W.R., Mendes-Rodrigues, C., 2009: Calculating germination measurements and organizing spreadsheets. Brazilian Journal of Botany 32, 849-855.

Rohlf, F.J., 1998. NTSYS-pc: numerical taxonomy and multivariate analysis, Setauket, New York, USA, Exeter Publishing.

Schillinger, W.F., Schofstoll, E., Alldredge, J.R., 2008: Available water and wheat grain yield relations in a Mediterranean climate. Field Crops Research 109, 45-49.

Singh, P., Ibrahim, H.M., Flury, M., Schillinger, W.F., Knappenberger, T., 2013: Critical water potentials for germination of wheat cultivars in the dryland Northwest USA. Seed Science Research 23, 189-198.

Soriano, J.M., Villegas, D, Sorrells, M.E., Roy, C., 2018: Durum wheat landraces from east and west regions of the mediterranean basin are genetically distinct for yield components and phenology. Frontiers in Plant Science 9, 80.

Wuest, S.B., Lutcher, L.K., 2012: Soil water potential requirement for germination of winter wheat. Soil Science Society of America Journal 77, 279-283. 